\title{
AN ANALYSIS OF ONLINE CLASS OF POSTGRADUATE COURSE CONDUCTED BY SARASWATI MULTIPLE CAMPUS DURING COVID-19 IN LOCKDOWN PERIOD
}

\author{
Yadav Mani Upadhyaya, PhD*
}

\begin{abstract}
:
COVID-19 has changed the way people around the world change their daily lives. Such a change took place not only in developed countries but also in developing countries. Such daily changes took place in the educational sector of the country as well as in other sectors. As a result, Saraswati Multiple Campus also changed its old academic calendar to conduct online classes. This article aims to inform all about the online classes conducted by Saraswati Multiple Campus during the lockdown period of COVID-19. This article is descriptive. However, in general, 60 students have been asked three questions each online and the data has been collected and explained based on that. Similarly, the general method for interpreting online classes is based on online information published by Tribhuvan University at different times, online information published by the campus administration, and various online related articles. Also, the summary of this article says that the online class conducted by the campus has been effective despite various problems.
\end{abstract}

Keywords: COVID -19, Online education, Virtual class, Technology friendly

\section{Introduction}

With the World Health Organization declaring COVID-19 as an epidemic in January 2020, the outbreak still has a major impact on the world. The world's health sectors, agricultural sectors, construction, energy, socio-economic system destroyed the entire sector. It also caused great damage to the education sector. From university to the school level, they formally postponed their studies. So it has affected education systems at all levels. Various educational conferences, educational training, educational classes have been canceled or postponed. Countries around the world used their schools, campuses, and universities for quarantine and isolation to prevent the spread of the disease. COVID-19 also changed people's thinking. Schools and colleges were used as quarantine and isolation at that time due to the idea that people should live first and education is needed only after survival.

As various universities, schools, and colleges around the world started postponing their classes; Nepal also postponed its classes. The Tribhuvan University also formally issued a notice on 8th Baishakh, 2077 BS. The committee was tasked with finding alternatives in the field of education. The committee was tasked with advancing the idea of conducting classes virtually, as there is no longer any physical presence in the university to take classes. Assistant Professor of Saraswati Multiple Campus (Humanities Faculty: Economics Department), Tribhuvan
University, Nepal. 
It was an opportunity for the underdeveloped countries including Nepal to conduct their studies through virtual classrooms in different developed countries of the world. The university had a good start, saying that it would be a great achievement to be able to run classes even in such a dire situation of lockdown.

The Saraswati Multiple Campus under Tribhuvan University also took the opportunity to conduct its classes as directed by Tribhuvan University. Based on the information provided by Tribhuvan University, Saraswati Multiple Campus has set a good example for its teachers and staff to be prepared for online classes through social media. This campus has been using this opportunity. We hope that this contribution will further contribute to the education sector in Nepal.

\section{Objectives:}

The main objective of this article was to inform us about the online classes conducted by Saraswati Multiple Campus and to individuals and organizations in the entire educational sector. However, this article deals with the following two objectives: To explain the successful operation of online classes by teachers, students and staff and to inform about the success of removing the psychological trauma through online classes.

\section{Scope}

The evaluation of this article is based on informal conversations, experiences, virtual presentations, observations, assignments, and the dynamics of online teaching with teachers, staff, and students. This article is based on the experiences, perceptions and perspectives presented here. The faculty, staff and students of this Saraswati Multiple Campus of Tribhuvan University were able to do their work online despite this turning point.

\section{Methodology}

In this method, only postgraduate (MBS, MBM, Economics, English, Sociology, and Nepali) students were included. Three questions per students collected from 60 participants from 6 different postgraduate streams will not get all the answers, this representation can understand the feelings of the students. Do the questions specifically try to understand the students' views on three main aspects such as were you involved in the online course before this? Are you satisfied with your online class? and is it necessary to study this subject physically after lockdown?

This study is descriptive and attempts to understand the experience provided by online education during periods of crisis and epidemic such as Covid-19. Likewise, in the explanation of this article, we have included information issued by Tribhuvan University at different times, information issued by the campus administration, ideas explained about online classes on social media. In addition, the Campus Head, Assistant Campus Heads, Department Heads, and Departmental Coordinators have been enlisted to further explain the activities of the online class. 


\section{Literature}

Mc. Brien (2009) in his article on online education embraces the possibility of learning online through any medium, at any time, in any situation. This greatly helps students who are physically unable to attend. The importance of online classes seems to be because they can be accessed from one's own office room or other places.

Singh and Thurman (2019), on the other hand, express the view that online classes do not teach students in the right way. He explained that the learning environment was not properly structured due to the inability of students to attend live lectures, the lack of real-time interaction between teachers and learners, and the lack of immediate response.

In this context, Basilia (2020) said that he has a positive opinion about online Kakghasha. According to Basilia, even amid such a spread of the virus, there is a need for online classes where (a) video conferencing with at least 40 to 50 students is possible, (b) classrooms can be kept organic with students, and (c) lectures are not just laptops but mobiles. They are also able to conduct classes on the phone and have (d) the possibility of viewing pre-recorded subject matter, and (e) the immediate response of students and assignments.

In this context Carrie (2020), he said that in the severe outbreak of the global epidemic COVID19 , many cities were transformed into ghost cities and its effects were seen in schools, colleges, and universities. In such a situation, all these online teaching and online education can be taken as a panacea for the crisis. The Coronavirus has created institutions to move from offline mode to online mode teaching mode. This forced the institutions to adopt modern technology. This tragedy has shown us the fascinating side of online teaching and learning. With the help of online teaching, we can give lectures to a large number of students anytime and anywhere in the world. All organizations should exchange different options for their online pedagogical approaches. We should try to make better use of technology. Many universities around the world have fully digitalized their work, realizing the dire need of the current situation. Amid this problem, online education is appearing as inevitability. Therefore, increasing the quality of online teaching is important. Online education at Chinese universities has grown rapidly since the COVID-19 outbreak. There were normal classrooms converted into classrooms overnight as e-classrooms. Teachers have changed their entire educational approach to face new situations and adapt to changing ones. The concern is not so much whether online teaching methods can provide quality education but how educational institutions will be able to adopt such a large online education even in such a difficult time.

Partlow and Gibbs (2003) explain the need to make online courses dynamic, fun, and interactive. Teachers should set time limits to make students aware. Efforts should be made to make the learning process as humane as possible. Students should pay personal attention so that they can adapt easily. Social media and various forums can be used to interact with students. Communication is the key when it comes to enabling students to practice through texts, various messaging applications, video calls, and so on, and also builds their skills. The quality of the curriculum should be constantly improved and teachers should strive to give them excellence. Online programs should be designed in such a way that they are creative, interactive, relevant, student-centered, and group-based. 


\section{TU Notice for Online Classes}

During the lockdown, Tribhuvan University had sent information at different times to make the classes of various online classrooms run by making alternative arrangements. Which we have explained here point by point:

1. On the 8th of Baisakh 2077, Tribhuvan University published a notice requesting its students to adopt alternative methods as regular classroom operations became uncertain. Dr. Mahannad Chalise, Director of Management, Open and Distance Education Center, under the coordination of Dr. Binil Aryal, Head Professor, Central Department of Physics. Director Gangaram Gautam and Acting Chief of the Vice-Chancellor's Office Bishnu Prasad Aryal had sent a notice to form a committee to study the issue.

2. On the same day of 8th Baishakh 2077, Tribhuvan University had informed another information to the campuses, schools, and departments. He thanked everyone for conducting online classes by the campus, school, and department on their initiative. It also requested that online classes be conducted as they are. The university has already provided the necessary software for this and will make it available in a few days, as well as legal arrangements for online classes.

3. Similarly, on the 10th of the same month, Tribhuvan University re-issued the information regarding the online class and sent the notice of the decision to allow the operation of the online class.

4. Similarly, another notice was sent on behalf of Tribhuvan University on the 12th of this month. In which the guideline 2077 related to conducting classes online has been prepared and it was informed that schools, colleges, and departments can get information from their own dean's office.

5. On 31st Aasad 2077, the Secretariat of the Tribhuvan University Assembly and the Executive Council issued a notice containing a 13-point code of conduct for further streamlining the online classroom, including action to be taken, calculating the operation of the online classroom as a regular classroom, and various other points. Was sent.

6. Tribhuvan University had sent information regarding online rights and issued instructions to the students and teachers to take and take online classes according to their policies and rules, which included various points.

7. Thus, on the Srawan 25th, information was sent based on the records of the teachers taking online classes

\section{Events of SMC in Online Class of Teachers and Students:}

Tribhuvan University had published various information about online education at different times. Based on the same information, Saraswati Multipurpose Campus has also taken the following steps to advance the learning activities through online classes, which are given below. 
1. The campus first discussed 8 AM on April 2, 2020, with the Campus Head, Assistant Campus Heads, Department Heads, and some teachers about the Zoom Cloud app to provide information about online classes.

2. Similarly, on April 5, realizing the need for further discussion about the Zoom Online class, a discussion was held with the teachers and staff at different levels of the campus as well as the MBM students. During the discussion, Assistant Professor Mr. JB Hamal explained how to present topics during Zoom Online.

3. On April 9, 2020, there was a discussion on conducting postgraduate online classes in subjects such as Sociology, English, Nepali, and Economics, which are being conducted under the evening program for the graduates.

4. For the first time, various online portal news of the country informed about the online classes being conducted in Saraswati Multiple Campus.

5. The google class was discussed by the college administration on April 18 to make online classes more convenient and easy to present.

6. On April 25, Tribhuvan University formally announced its intention to introduce the virtual class to some of the administrative staff of its various affiliated campuses and also to some other people about the online class.

7. The college family all came together about the online class and were formally introduced to the google class.

8. On May 4, 2020, the MBM Club, created by the MBM students of Saraswati Campus, conducted a program called 'Banking and Entrepreneurship and Way Forward' on the campus under their leadership. For that, Suman Pokharel CEO IME Group Global IME Bank had given training to the students.

9. On May 12, a program called Startup Ecosystem in Nepal was conducted on this campus under the leadership of MBM students.

10. Thematic discussions were held on May 24 under the leadership of Saraswati Campus to provide more information to the covid-19 that appeared in Nepal. Former Executive Director of Nepal Rastra Bank Nar Bahadur Thapa explained about the 'Budget and Monetary Policy' and Professor Shivaraj Adhikari has discussed in the topic of 'The Impact of COVID-19 on Nepalese Economy'. The college family felt that their capacity has been enhanced.

11. On May 30, on behalf of the Saraswati Campus family, an online class meeting was held with all the teachers, staff, and students in one place.

12. On June 3, Dean Professor of Management Dr. Dilli Raj Sharma monitored the class and gave various suggestions in the online class.

13. On June 5, Saraswati Campus again conducted an online class by co-founder media arc inc Pushkar Sharma on 'Digital Marketing Effectiveness'. 
14. A panel discussion on 'COVID-19 and Economic Recovery' was held on June 7 under the leadership of Saraswati Campus. Dean Professor of Management Dr. Dilliraj Sharma, Special Guest Rameshwar Khanal, Chairman Vasudev Adhikari Nepal Bank Ltd. Discussions were held.

15. Prashant Gautam, Nabita Paudel, Campus Head, Assistant Campus Head, Janak Poudel, trained on team Microsoft to inform about Microsoft, another reliable medium of an online class, as there is some information about various problems of an online class in jun8 and due to time constraints in zoom cloud. Was provided.

16. On June 14, Office365 and teams Microsoft training professors Dr. Sanjay Shrestha, Devnarayan Yadav, Rama Baskota, Devi Lal Timisina, and Rom Kant Pandey worked to make the online class more effective.

17. On June 17, Tribhuvan University informed that proposal defense and thesis defense can be done from home as well. Various discussions were held in this regard at Saraswati Campus as well.

18. On June 29, training was provided to the teachers and staff of the Saraswati Multiple Campus under the theme "New Direction in Evolution System of Higher Education". Chief guest Professor Dr. Shivlal Bhusal Rector Tribhuvan University, Professor Dr. Suvarna Shakya, former DECE Tribhuwan University, director SOMTU Mahananda Chalise, educationist Professor Dr. Mana Wagle conducted the discussion.

19. The thesis was discussed in an online class on July 21. According to the MBS, 5 of the first semester students were trained in thesis viva in the physical presence of the Campus Head and Assistant Campuses.

20. Similarly, MBS first semester students of Saraswati Multiple Campus were formally taken the online exam on July 30,31, August 1, and 2.

21. According to Saraswati Multiple Campus, its teachers and staff have been imparting training and seminars online at various times.

22. Similarly, on September 7, a separate program titled "Tomorrows higher education and our universities" was trained by various guests, including the Chief Guest, Prof. Dr. Bhim Prasad Subedi, Chairman, UGC Nepal, presenter Prof. Dr. Binil Aryal, IOST TU Professor Dr. Suvarna Shakya Dr. Megh Mahat Dr. Rudra Kafle provided the training. Its organizer was Nepal University Teachers Association Central Committee Kathmandu Nepal.

23. Similarly, on September 8, the Saraswati Campus family was trained by Deputy Executive Director Dr. Navraj Adhikari under the title 'Securities Markets in Nepal'.

24. To strengthen the team training on 13th September, MBS third semester students were trained.

25. 19 September at $5 \mathrm{pm}$ a training was arranged under the leadership of Nepal University Teachers Association University Campus TU Kirtipur under the title of 'Final Examination during Pandemic Global Practices and Alternative Models for TU' Chief Guest Professor Dr. Dharmakanta Baskota VC TU, Educationist professor Dr. Vasu dev 
Kafle, Prof. Dr. Danda Bahadur Rawat and moderator Dean Management of Prof. Dr. Dilli Sharma and the commentators had their different views and the Saraswati Multiple Campus family also attended the event from which they got a chance to be informed.

26. 26 September, Saturday 2020 at 7 AM Ministry of Finance Secretary Shishir Kumar Dhungana Guest Speaker under the headline "Challenges in Budget Execution" provided additional training and further training to this Saraswati Multiple Campus family.

27. Oct. 2020, Saraswati Multiple Campus teachers, staff, and students from 7.30 am onwards under the title 'Challenges in Economic Development in Nepal'. Guest Speaker Vice-Chairman and NPC Government of Nepal Dr. Pushparaj Kadel and Special Guest Dean Faculty of Management Professor Dr. Dilli Raj Sharma, this work was done to further train the family.

The work of Saraswati Multiple Campus to train its students, teachers, and staff at different times through its online classes and to further its educational activities seems to be highly commendable. We are proud of the fact that the families of this campus have been able to carry out their educational activities due to the intimacy and awareness shown by the teachers and staff as well as the students despite various problems during this period of lockdown. While the impact of COVID is still there but the lockdown is over, various campuses and universities have started their educational activities physically. Similarly, Saraswati Multiple Campus has also started its educational activities physically. Online classes are still being conducted on various subjects for postgraduate students. While conducting online classes in this way, the team software seems to have been adopted by all the subject teachers who were formally allowed to operate by Tribhuvan University.

At different times, various online portal news outlets had spread news about the Saraswati Multiple Campus conducting its educational activities through online classes. We had received news on various social networks that Saraswati Multiple Campus was conducting online classes even though other campuses were not able to conduct their online classes. Therefore, as directed by Tribhuvan University, this Saraswati Multiple Campus also carried out its educational activities.

\section{Results and Discussion}

There were certainly some dilemmas at the outset when classes were conducted online all of a sudden, as OVID-19 had traditionally taught various postgraduate subjects in physical presence. Although this teaching method is completely new for the students, it has made the level of education satisfactory. The answers to the questions asked by the students say that the hard work of the teachers is commendable in itself. This will make a separate contribution to the education sector.

Computer-based training not only imparts knowledge of the subject to the students by suddenly entering the virtual classroom from the traditional classroom but also made the teacher more technology-friendly than the student and guided them in the 21 st century. The learning experience of the students also became different. When the teachers taught their subjects through computer slides, the students also got their teaching material easily. Although not as full of physical 
presence, the online classroom provided students with a fun environment in the virtual classroom, good question and answer efforts, classroom planning, aspiration to understand technology, and motivation.

Of course, online classes were not possible for all students, but students showed up in virtual classes as much as possible. It motivated students to stay psychologically healthy and increase their thematic knowledge.

As the teachers recorded and distributed the video they taught, it also helped the rest of the students who could not attend the virtual class. In this way, it helped the students present in the class and the absent students.

Since Nepal telecom has arranged a data package for the students, it also helped such a class well. Not all students have access to computers, laptops, mobiles, MacBooks, Tab which has affected their attendance.

Based on the 3 main questions asked to the postgraduate students, their answers can be presented in a simple way here. Like you were involved in the online course before this? More than 95 percent of the students answered no, and it is clear that many students did not belong to the online class. Are you satisfied with your online class? More than 80 percent of the students answered that they were satisfied. Since it is the time of lumbering, its usefulness was also understood correctly. Also, in the last question, is it necessary to study this subject physically now? About 87 percent of the students answered that it was not necessary. This means that students are also satisfied with the online class.

Probably because postgraduate education in university education is a higher level study, more than 80 percent of the students have found that this study has been properly explained. That is, it was found to be supported. However, not all students were satisfied. Although Saraswati Multiple Campus is not a private campus in itself but a government campus in terms of university education, it provides a good example that it can provide education to its students even in adverse times. In which campus administration, student teachers, and various other parties have made a significant contribution.

\section{Benefits from Discussion:}

- The use of online tools flourished significantly during this time. Many professors and students were able to search for information and materials through online blogs, documents, websites, and other related resources.

- Opportunity for live cloud recording of the training, meetings, interpretation analysis, and other interactions.

- Increased use of available resources.

- Exposure of training for trainers by the various digital teaching and learning materials provided by the University for the use of the software.

- Learning opportunity for collaborators

- Purchase of new technological facilities and licenses for the University 
- Students and staff can explore education options using technology and other online tools for education and learning

- Professors and university administration seek opportunities for the development of mixed education.

- Opportunity to work far away,

- The message that education can be taken even outside the classrooms of traditional universities

\section{Challenges from Results}

While conducting online classes, this Saraswati Multiple Campus had to face various challenges. Due to the current downturn in the country and the direct risk of COVID-19, there was a risk of unplanned online classes.

- Lack of internet access in many villages of students, staff, and teachers

- Inconvenience of computer, laptop and/or tablet or mobile required for online

- Lack of adequate training for students and professors.

- the inability to use the laboratory or fieldwork due to social distance;

- Slow down due to sudden heavy demands of the internet

- Irregularity of power supply

- Low student engagement

- Teachers neglect students

- Deadline

- $\quad$ Lack of monitoring and evaluation

- Inability to use technology equipment services

- Many students found the online method cumbersome,

- Students in the village are forced to do housework

- Some students appear to be mentally scared and anxious.

- Risks of viruses, hacking, and other cyber security risks on computers and other portal devices

\section{Conclusion}

COVID-19 affected Nepal in the same way that it affected different countries. Such an impact has been felt in universities, various campuses, schools, and educational departments as well. Such an effect is not only negative but also positive. The online classes conducted at Saraswati 
Multipurpose Campus in the early days had various difficulties in conducting the classes. But gradually we find that all the teachers, staff, and students are gradually adjusting to this online class.

It is a positive thing in itself that students, teachers, and staff are able to share their knowledge with their students even when there is a compulsive mentality of having to stay at home in case of a lockdown. On the one hand, it has guided the psychologically frustrated students to the right path; while on the other hand, the teachers and staff were happy to be able to carry out their educational activities even in the state of psychology.

Of course, there were various problems during the online class. Students could not easily access the Internet. Although there was internet in the cities, there was no internet in various rural areas. Students and teachers could not use it easily. Also, the Internet alone did not ease the situation as both teachers and students needed a computer, laptop, or mobile phone. In some families, the parents had to teach at the same time and the children had to study at the same time. Of course, using computers and laptops or mobiles was not easy.

Explaining the various answers to the questions posed while conducting online classes involving students studying various subjects at Saraswati Multiple Campus, it is seen that although all these students were not satisfied with it, about 80 percent of students were satisfied with the education provided during difficult times. Also, it has definitely provided satisfaction to the employees or various other parties.

\section{Recommendations}

The Saraswati Multiple Campus of Tribhuvan University proved to be relatively good in conducting online classes by overcoming various obstacles even during the lockdown in the middle of COVID-19. However, based on its experience, the following recommendations will help move the education system forward in times of crisis.

- Our Saraswati Multiple Campus is as new in online education as the majority of students in other countries. So most of the students are not able to use computer tools effectively. Students do not have personal computers, no internet access, and no facilities. So you have to recognize the reality.

- For the easy and successful launch of online education, government and university officials should provide tools free of charge or at a discounted rate. The government provides internet hubs in public places.

- University officials should step up their efforts to provide free online classroom training through television, radio, newspapers, social media, etc.

- Using the same type of online portal

- $\quad$ To bring uniformity in the use of mail and other private networks. From which to contact the school administration effectively.

- Students and staff should be encouraged and reassured.

- $\quad$ Reducing course loads 
- Teaching materials should be simplified

- Calendar must be used.

- Students should be focused.

- Easy online delivery management

- Alternative forms of assessment should be considered

- Interaction model, oral presentation, creative projects should be the focus.

\section{References:}

Keeton, M. T. (2004). Best online instructional practices: Report of phase I of an ongoing study. Journal of Asynchronous Learning Networks, 8(2), 75-100.

Kim, K.-J., Bonk, C. J. (2006). The future of online teaching and learning in higher education: The survey says. Educause Quarterly, 4, 22-30.

Liguori, E. W., Winkler, C. (2020). From offline to online: Challenges and opportunities for entrepreneurship education following the COVID-19 pandemic. Entrepreneurship Education and Pedagogy. https://doi.org/10.1177/2515127420916738

Littlefield, J. (2018). The difference between synchronous and asynchronous distance learning. https://www.thoughtco.com/synchronous-distance-learning-asynchronousdistance-learning-1097959

Mc Brien, J. L., Cheng, R., Jones, P. (2009). Virtual spaces: Employing a synchronous online classroom to facilitate student engagement in online learning. The International Review of Research in Open and Distributed Learning, 10(3), 1-17.

Partlow, K. M., Gibbs, W. J. (2003). Indicators of constructivist principles in internet-based courses. Journal of Computing in Higher Education, 14(2), 68-97.

Singh, V., Thurman, A. (2019). How many ways can we define online learning? A systematic literature review of definitions of online learning (1988-2018). American Journal of Distance Education, 33(4), 289-306.

Singh, V., Thurman, A. (2019). How many ways can we define online learning? A systematic literature review of definitions of online learning (1988-2018). American Journal of Distance Education, 33(4), 289-306

Song, L., Singleton, E. S., Hill, J. R., Koh, M. H. (2004). Improving online learning: Student perceptions of useful and challenging characteristics. The Internet and Higher Education, $7(1), 59-70$. 